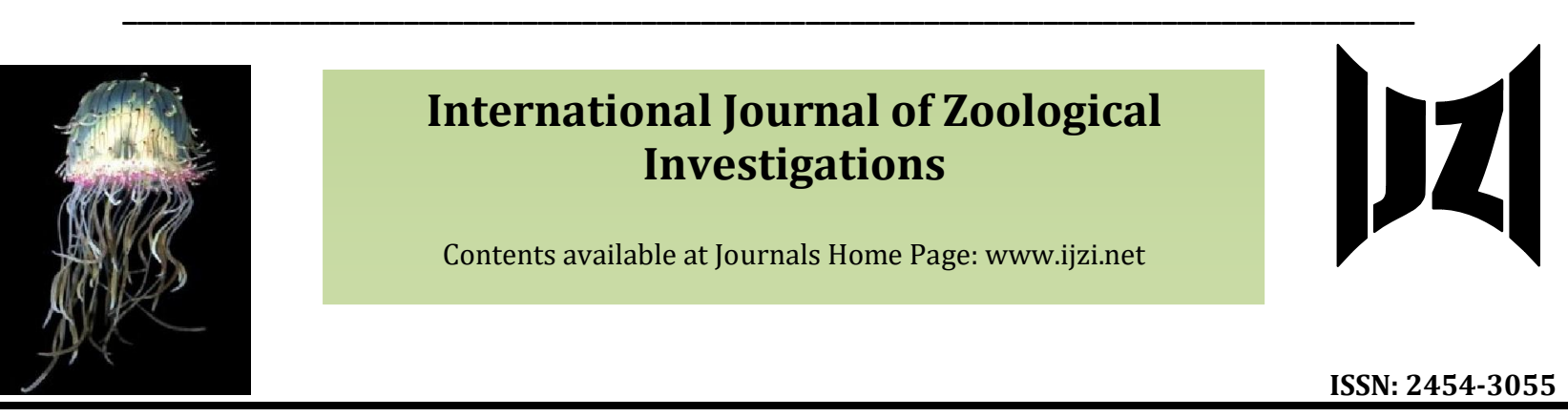

\title{
Histopathology of Fish Liver to Assess the Water Quality of Limoeiro Stream, Floresta Azul, Ba, Brazil
}

\author{
Flores-Lopes Fábio ${ }^{1 *}$, Brito Nathália C. ${ }^{1}$, Cruz Arielle 0. ${ }^{1}$ and Paulo Driele, V. ${ }^{2}$ \\ ${ }^{1}$ Department of Biological Sciences, Universidade Estadual de Santa Cruz (State University of Santa Cruz) - UESC, Rodovia Ilhéus- \\ Itabuna, km 16, 45650-000, Ilhéus, BA, Brazil, \\ 2Laboratory of Ecotoxicology, Zoology Department, Universidade Federal de Pernambuco, Recife, Brazil
}

${ }^{*}$ Corresponding Author

Received: $17^{\text {th }}$ September, 2019

Accepted: 20th October, 2019

https://doi.org/10.33745/ijzi.2019.v05i02.004

\begin{abstract}
This study was aimed to verify the water quality of Limoeiro stream, which is a small tributary of Cachoeira river, through the histopathological analysis of the liver of Hypostomus cf. unae. Forty seven specimens have been collected by electrofishing at two sampling points. The routine histological techniques have been used in the analysis. The most frequent histopathological changes were vacuolation of hepatocytes and rectillination of sinusoidal vessels; furthermore, hepatocytes were found to be irregularly distributed and had round and large nuclei surrounded by elongated sinusoid vessels. Analyses have shown that point 2 had worst water quality than point 1 , as indicated by a higher occurrence of moderate and severe alterations. Results have revealed that Limoeiro stream had a reasonable water quality, but to perform a more precise analysis of this water body, more detailed studies that adopt different methodologies are essential.
\end{abstract}

Keywords: Water quality, Hepatocytes, Liver, Histopathological alteration index

Citation: Flores-Lopes Fábio, Brito Nathália C., Cruz Arielle O. and Paulo Driele, V.: Histopathology of Fish Liver to Assess the Water Quality of Limoeiro Stream, Floresta Azul, Ba, Brazil.Intern. J. Zool. Invest. 5 (2): 31-42, 2019. https://doi.org/10.33745/ijzi.2019.v05i02.004

\section{Introduction}

The quality of aquatic ecosystems can be evaluated through analyses of physical, chemical and biological parameters. Nevertheless, when it comes to long periods of exposure, biological parameters have the advantage of providing information on water quality especially if sessile organisms or those living near the bottom are considered, since they better reflect the overall ecological condition of the water body (Navas-Pereira et al., 1996). The use of fish in environmental monitoring studies has several advantages, as 
they are directly associated with the sediment and water column, have poor mobility and exhibit some physiological mechanisms of biological response (Jenkins, 2004).

According to Cairns Jr. et al. (1993), the ability to protect ecosystems depends upon the ability to distinguish effects of human action from natural changes, in an effort to categorize the influences of human actions on the biological system. Accordingly, the use of biological parameters to evaluate the quality of water is based on the biological changes of organisms as a function of the environment where they live. As rivers are subjected to various disorders, the aquatic biota reacts to either natural or anthropogenic stimuli.

Bengtsson et al. (1975) stated that the occupation and distribution of fish can be influenced by a number of biotic and abiotic factors such as temperature, $\mathrm{pH}$, salinity, substrate type, nutrient availability and reproductive strategies. The negative effects of anthropic actions on fish communities usually derive from the presence of pollutants, whereas other effects are associated with changes in the basin hydrology and changes in the habitat and energy sources that depend on aquatic life. The knowledge of the effect of pollutants on aquatic organisms chiefly derives from mortality experiences that often occur in short periods of time. Karr (1981) reported that fish communities can provide important information about the aquatic environment and, for this reason, are excellent indicators of environmental quality.

Adams (1990) stated that histopathological biomarker are extensively used to record and quantify exposure to, and the effects of, environmental pollutants. Used as exposure monitors, these biomarkers have the advantage of quantifying pollutants that are biologically available. These biomarkers can integrate the effects of various stress factors and help elucidate the mechanisms of action.

Histology is an efficient method to detect irritant effects, particularly some chronic effects in various tissues and organs (Bernet et al. 1999). Although it is important as an indicator of exposure to contaminants, histology is a great tool to assess the degree of pollution, particularly chronic and sublethal effects. Schwaiger et al. (2004) opined that the use of histopathological analysis to identify specific physical and chemical stresses has seldom been used because most measurements of the extent and severity of the lesions have been subjective and nonquantitative. Histological changes could be an alternative indicator of toxic pollutant levels in water and, at least in some organs, they were shown to present a good dose-response relationship (Au, 2004; Abdel-Warith et al., 2011).

Stegeman and Lech (1991) have demonstrated that the liver of teleosts is a multifunctional organ responsible for the conversion of food, vitellogenin production during the growth of gonads and detoxification of toxic compounds. Liver is the largest organ of metabolism and has the potential for biotransformation, bioactivation and excretion of xenobiotics. It is in direct contact with pollutants absorbed from the environment (Gonzalez et al., 1993; Bernet et al., 1999). Gernhofer et al. (2001) demonstrated that fish liver histology could serve as a model for studying the interactions between environmental factors and hepatic structures and functions. 
Hypostomus is a genus that belongs to the order Siluriformes and is one of the most specious neotropical taxa, entailing a number of problems concerning the real taxonomic limits of their species (Miranda and Mazzoni, 2003). These species are benthic and have a preference for running waters that percolate into bedrocks, where they live scraping algae that grow on rocks (Britsk et al., 1999; Mazzoni et al., 2010). Color pattern and morphology exhibit a wide diversity, hindering the identification of species, particularly those with large geographic distribution (Rubert et al., 2008). In studying the fish fauna of Limoeiro stream, Trindade et al. (2010) have observed a high presence of the species Hypostomus cf. unae (Steindachner, 1878) at the sampling point, which caused it to be chosen as object of the present study.

The Cachoeira river basin covers one of the most important socio-economic regions of Bahia state, located in northeastern Brazil (Nacif, 2000). The basin undergoes intense degradation, notably due to the discharge of untreated sewage, the use of fertilizers and pesticides on cocoa plantations located around the river, and the illegal use of tanneries on the banks (Souza et al., 2009). Klumpp et al. (2002), Mangabeira et al. (2004), Paulo et al. (2012) and Lucio et al. (2012), reported that this basin is undergoing a process of environmental degradation.

The aim of this study was to evaluate the water quality of Limoeiro stream based on the occurrence of histopathological alterations in the liver of Hypostomus cf. unae (Steindachner, 1878).

\section{Materials and Methods}

The Cachoeira river basin is located in the south of Bahia state, northeastern Brazil, between coordinates " $14^{\circ} 42^{\prime} / 15^{\circ} 20^{\prime} \mathrm{S}$ and $39^{\circ} 01^{\prime} / 40^{\circ} 09^{\prime} \mathrm{W}^{\prime}$. Its drainage area, including the Santana river basin, is $5,561 \mathrm{~km}^{2}$ and covers 12 cities: Firmino Alves, Floresta Azul, Santa Cruz da Vitória, Itajú do Colônia, Ibicaraí, Itapé, Buerarema, Jussari, Itabuna, Ilhéus, Itororó and Itapetinga. The population living in the basin area of Cachoeira river is near 600,000 inhabitants. At the north, the territory is limited by the river basins of Contas and Almada rivers; at the south, it is limited by the drainage areas of Pardo and Una rivers; at the west, by the drainage areas of Pardo river and, at the east, it is limited by the Atlantic Ocean (Nacif, 2000).

According to Trindade et al. (2010), Limoeiro is an over $11 \mathrm{~km}$ long small permanent stream located near the town of Floresta Azul; the stream flows into the Salgado river, which is one of those that eventually form the Cachoeira river. Sampling points were defined from the study of Trindade et al. (2010), considering their position in the basin and accessibility to the stream (Fig. 1). The following points have been chosen: Point 1 (14 57' 57.6" S e 39o 41' 42.9" W): mean depth from 0.10 to $0.33 \mathrm{~m}$, width ranging from 0.72 to $3.11 \mathrm{~m}$, and mean surface water speed of $0.50 \mathrm{~m} / \mathrm{s}$, steep landscape without riparian vegetation; clear water and fast speed, sandy substrate and rocks exposed on the surface; Point 2 (14\% 54' 48.8" $\mathrm{S}$ and $39^{\circ} 43^{\prime} 55,5^{\prime \prime} \mathrm{W}$ ): depth between 0.26 and $0.89 \mathrm{~m}$; surface area of 2.50 and 8.20 $\mathrm{m}$ in width; average water speed of $0.3 \mathrm{~m} / \mathrm{s}$. The presence of small trees and grasses can be observed in the environment. The substrate is 


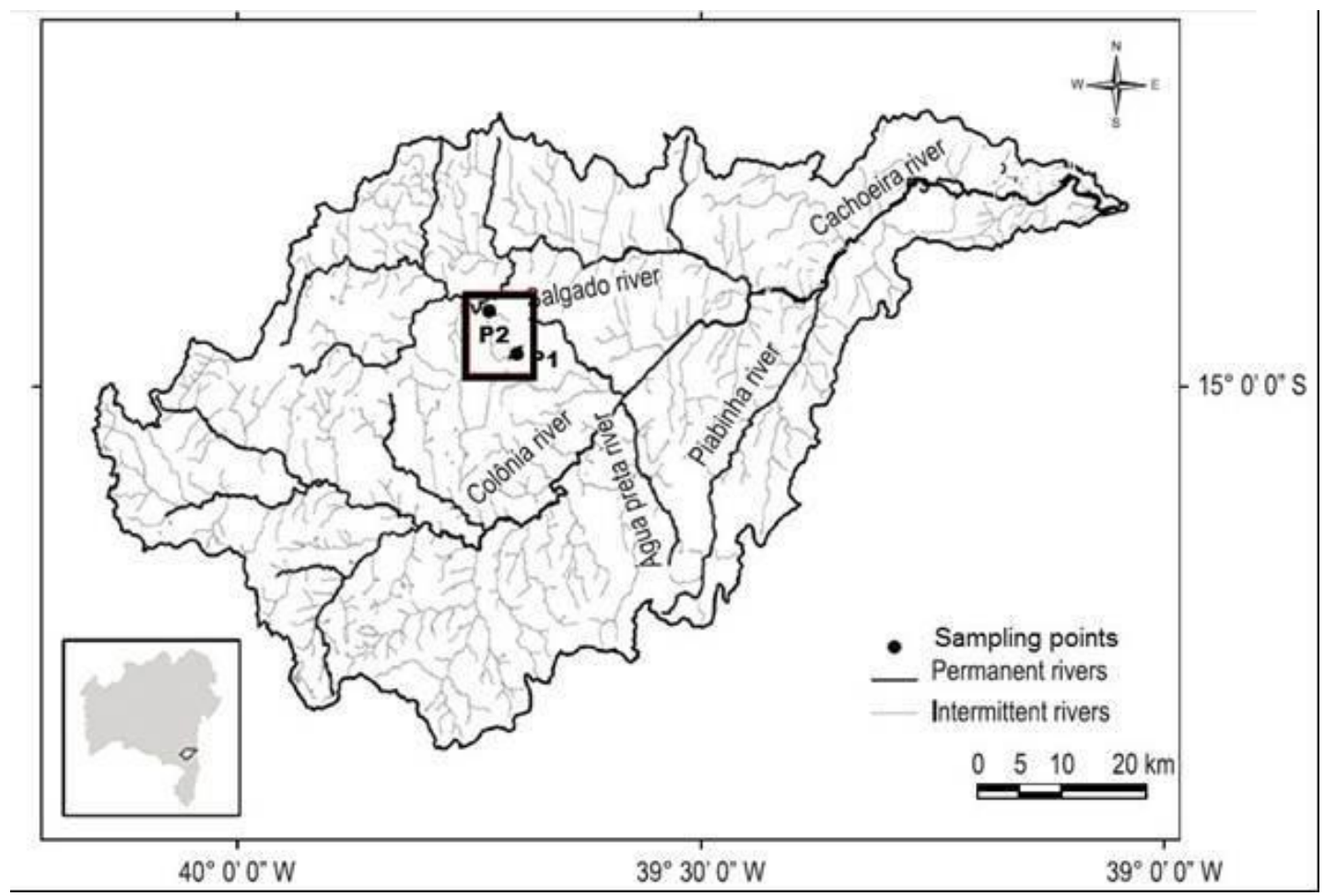

Fig. 1:- Map of the Hidrographic basin of Cachoeira river, indicating the sampling points. Point 1 and Point 2 on the Salgado River.

rocky and has areas through which water flows faster. 47 specimens of the species Hypostomus cf. une (thirty from point 1 and seventeen from point 2) were collected between March and December of 2007. The total length ranged between 31 and 112.9 $\mathrm{mm}$, while the average weight was $174.43 \mathrm{~g}$.

Based on the methodology proposed by Suzuki et al. (1997) and Mazzoni et al. (2000), fish were collected by electrofishing. Two operators dressed in insulating rubber jumpsuit equipped with electrodes connected to dip nets that combined back and forth movements over a 75-100 $\mathrm{m}$ stretch in the downstream/upstream direction and thus captured fish by immobilizing them with the use of electric currents (Trindade et al., 2010).
Four samplings were carried out in 2007, in March, June, September and December. After sampling, the specimens were anesthetized with MS222 (Ethyl 3aminobenzoate methanesulfonate salt) at a concentration of $200 \mathrm{mg} / \mathrm{L}$. The specimens were placed in labeled plastic bags and were immersed in a solution of $10 \%$ formalin. The samples selected for histological study were fixed in formalin for one week.

The fish were taken to the Laboratory of Biological Oceanography of Universidade Estadual de Santa Cruz (UESC), where they were washed, weighed, measured, sorted and identified to species level. After this process, the material was preserved in alcohol solution 
$(70 \%)$ and deposited in the scientific collection of UESC.

Liver was extirpated from specimens and processed by routine histological techniques, embedded in paraffin, and sectioned at 5-7 $\mu \mathrm{m}$. Hematoxylin and eosin (HE) staining was used for a general viewing of the affected tissues and organs (Michalany, 1980). Histopathologic alterations were classified on a scale from 0 to 3 , where $0=$ no alteration; 1 = light alterations; 2 = moderate alterations; 3 $=$ severe alterations (Hose et al., 1996). Definitions of light, moderate and severe alterations followed Flores-Lopes and Thomaz (2011) and were characterized as follows: light alterations (1) - those that do not damage the liver tissues in such a way that improved environmental conditions allow for restructuring and resuming the functioning of a normal liver. These alterations are restricted to small parts of the liver. Moderate alterations (2) - more severe alterations that affect tissues involved in the functioning of the organ; these are repairable injuries, but if large areas of the body are affected or maintained under chronic pollution conditions, these can cause severe alterations. These alterations occur in almost the entire surface of the organ. Severe alterations (3) recovery of the liver structure is not possible even when the quality of water is improved or as the exposure to toxic stimuli ends.

The presence of histopathological alterations in each organ was semiqualitatively evaluated by the degree of tissue alteration (Histopathological alteration index HAI), which is based on the severity of lesions (Table 1). In order to calculate the HAI adapted from Flores-Lopes and Thomaz (2011), the alterations of each organ were classified into progressive stages of tissue damage. HAI was calculated for each animal using the formula: $=$ HAI $(1 \mathrm{X} \mathrm{SI})+(10 \mathrm{X} \mathrm{SII})+$ (100 X SIII), where I, II and III correspond to the number of alteration stages 1,2 , and 3 ; in turn, $\mathrm{S}$ denotes the sum of alterations in a particular step.

HAI values between 0 and 10 indicate normal functioning of the organ; values between 11 and 20 indicate light organ damage; between 21 and 50 denote moderate alterations; between 50 and 100 reveal severe alterations and above 100 mean irreparable injuries to the organ (Flores-Lopes and Thomaz, 2011).

The nonparametric test of Mann-Whitney for independent samples with $\mathrm{p}<0.005$ has been used to compare the mean values of alterations in the liver. Using a nonparametric ANOVA, differences between the sampling sites were tested for each parameter. The results regarding each station were compared by Mann-Whitney test. The significance level was $95 \%$ (Zar, 1999). Statistical analysis was performed using the Past software, version 1.11. Some cases were selected and photographed under an inverted light microscope fitted with a digital camera.

\section{Results}

Histological analysis showed that the liver had the same pattern of teleosts, being surrounded by a capsule of connective tissue and hepatocytes, with a large rounded nucleus and a marked nucleolus. It was observed that hepatocytes formed strands delimited by small blood vessels called sinusoids, which radiate out of the portal vein (Fig. 2A). Between the sulcus, small bile ducts can be seen occasionally. These are formed by a simple cubic epithelium surrounded by connective tissue and were observed close to 
Table 1: Classification of the severity of histopathological alterations seen in the liver of Hypostomus cf. unae Adapted from Poleksic e Mitrovic-Tutundzic (1994).

\begin{tabular}{ll}
\hline Stages & Changes \\
\hline I & Melano macrophage center \\
& Vacuolated cytoplasm \\
& Irregular formo f the hepatocytes \\
& Eosinophil granules in the cytoplasm \\
& Nuclear hipertrophy \\
& Celular hipertrophy \\
& Irregular nuclei \\
& Lateral position of the nucleus \\
& Leukocyte infiltration \\
\hline II & Degeneration of cytoplasm \\
& Degeneration of the nucleus \\
& Pyknotic nuclei \\
& Vacuolated nuclei \\
& Rectilineation of vessels and parenchyma \\
\hline III & Focal necrosis \\
& Tumor \\
\hline
\end{tabular}

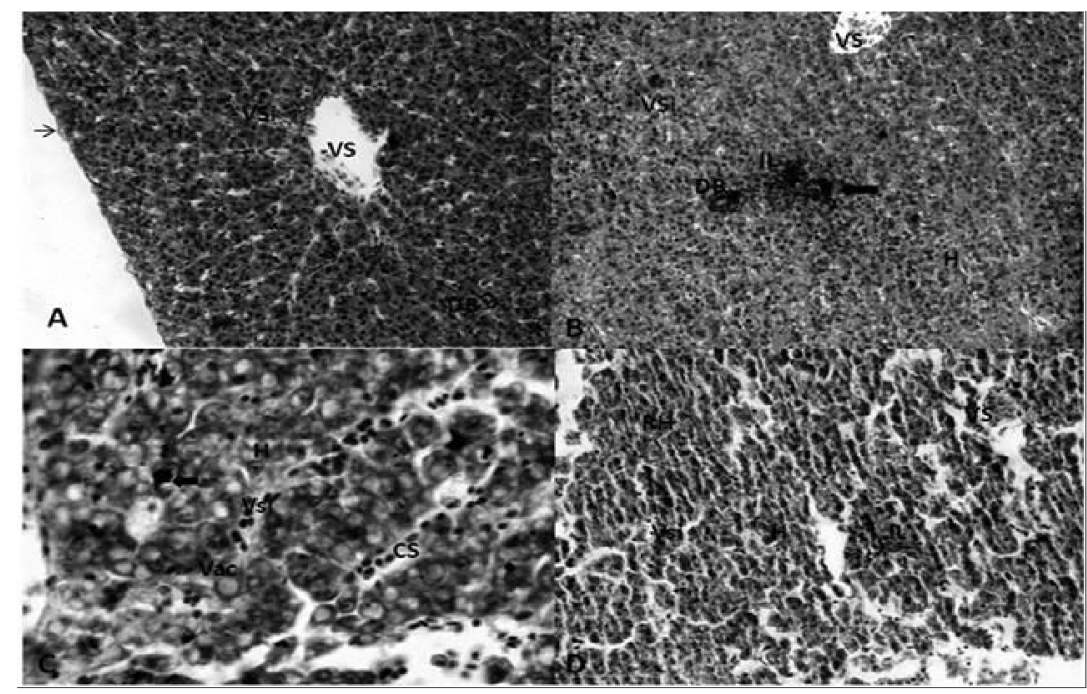

Fig. 2: Histological sections in the liver of Hypostomus cf. unae A - normal liver, H \& E (100X). B - Infiltrations of leukocyte and lipofuscin granules into the liver, H \& E (100X). C - Vacuolation of hepatocytes, H \& E (400X). D - Rectilineation of hepatocytes and sinusoidal vessels, H \& E (400X). H - hepatocytes; BV - Blood vessel; VSi sinusoid vessels; BD - Bile duct; SC - Slood cells; Vac - vacuoles; LI - Leukocyte infiltration; RH - Rectilineation of hepatocytes; thin arrow - connective tissue capsule; thick arrow - lipofuscin granules. 


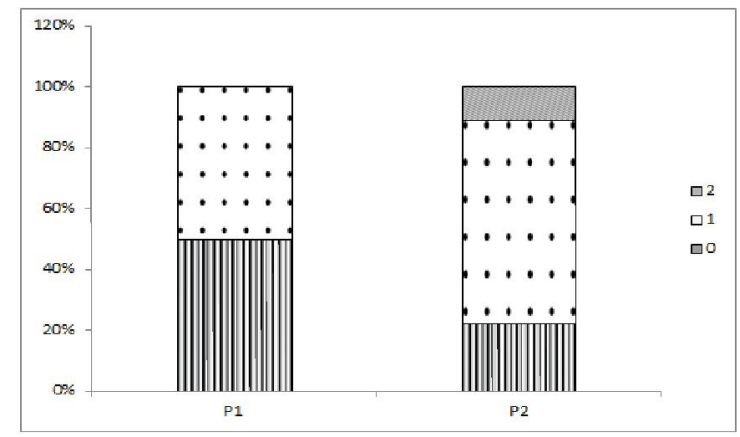

Fig. 3: Relative frequency of histopathological changes observed in the liver of Hypostomus cf. unae per sampling point in Limoeiro stream. $1=$ light changes; $2=$ moderate changes; $3=$ severe changes.

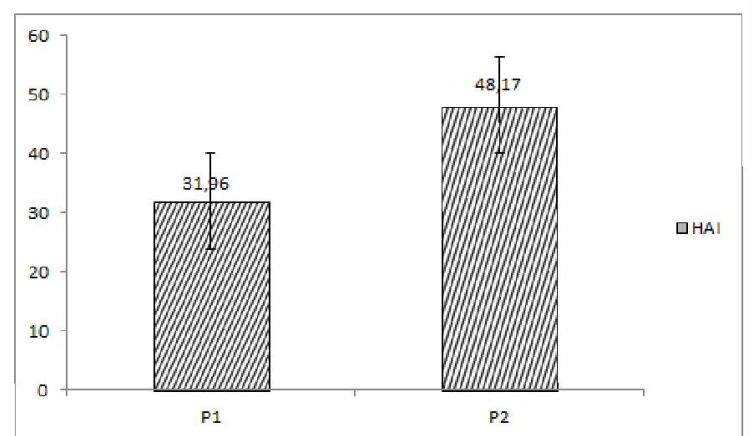

Fig. 4: Index values of histopathological alterations (HAI) in the liver of Hypostomus cf. unae regarding the sampling points in Limoeiro stream. Vertical line - Standard Deviation. the exocrine pancreatic tissue or isolated in the hepatic parenchyma (Fig. 2B).

Among the mild histopathological alterations observed, the most frequent were leukocyte infiltration, irregular hepatocyte form, cell degeneration and cytoplasmic vacuolization, and more than one vacuole per cell were normally observed (Fig. 2C). The occurrence of severe changes such as focal necrosis and formation of fibroids in small parts of the body were noticed. In two individuals from point 1 (6.6\%), the occurrence of parasites associated with hepatic tissue was observed.

The occurrence of senoidal vessels and other vessels with aggregation of red blood cells was observed in certain regions of the body (Fig. 2C). A high frequency of macrophages, fibroblasts and lymphocytes present in connective tissue of body filling was observed (Figs. 2B, 2D). It was observed that the specimens had vacuolated cytoplasms, and these organs had a rounded shape when compared with the rest of the cell. Some specimens showed alterations in liver cells arranged in cordonal shape, showing some regions of the body with hepatocyte and sine-vessel rectilineation (Fig. 2D).

Lipofuscin granules were observed in 10 of the 17 animals observed, and the largest amount was discerned near the connective tissue capsule of the liver. The analysis showed that the granules were dispersed throughout the body, being more frequent in the central region of the organ. The occurrence of granules was observed more frequently in individuals collected in the months of June and December.

96.6\% (29 fish) of the individuals of point 1 presented some type of mild alteration (1) in the normal pattern of the hepatic parenchyma, 90\% (27 fish) moderate (2), such as rectilineation of sinusoidal vessels and $10 \%$ (3 fish) severe changes (Figs. 2D, 3). At this point, degeneration and vacuolization of the cytoplasm were observed as moderate change and fibroids formation was observed as severe alteration.

Point 2 showed that $64.7 \%$ (11 fish) of the individuals had mild changes (1) in the 
normal pattern of the hepatic parenchyma, $100 \%$ (17) presented moderate (2), such as rectilineation of sinusoidal vessels and $52.9 \%$ (9 fish) presented severe alteration (Figs. 2D, 3 ). In the specimens of point 2, it was observed that the vacuolated hepatocytes observed in all animals showed a large cytoplasmic volume. The analysis revealed an irregular size in the cells' format, straight sine vessels and degeneration of the cytoplasm. The cytoplasm of the hepatocytes of some specimens collected showed vacuolization and slightly basophilic staining.

The results of the histological analysis showed that the water of the river at point 1 had a better quality when compared to that of point 2 , due to the fact that at point 1 a higher frequency of mild and moderate alterations was observed and a low frequency of severe alterations. The results showed that point 2 presented a poor water quality due to a higher frequency and severe alterations.

The HAI analysis also showed that point 1 had a better water quality, since at this point an average of 31.9 was observed and point 2 showed an average of 48.1 (Fig. 4). The fact that point 2 presented a higher HAI value was due to the fact that individuals presented a higher frequency of moderate and severe alterations in relation to the occurrence of mild alterations (Figs. 3, 4), characterized mainly by alterations in the hepatic parenchyma, such as degeneration of the cytoplasm.

The results observed by the statistical analysis did not show a statistically significant difference between the two points $(\mathrm{P}=0.18$ and $P=0.36$, respectively).

\section{Discussion}

Gonzalez et al. (1993), Petcoff et al. (2006) and Flores-Lopes and Malabarba (2007) described the general pattern of teleosts and the results of this study demonstrated that the liver of Hypostomus cf. unae has the same pattern observed in most teleosts. Petcoff et al. (2006) have pointed out that the liver has a primary arrangement based on the provision of hepatocytes, bile ducts and sinusoidal vessels, whereas structural differences between the species occur in the threedimensional organization of the stroma and parenchyma. According to Bruslé and Anadon (1996), the liver is a dense organ located in the ventral cavity of the abdominal region. The size, shape and volume are adapted to the space available between other visceral organs.

The types of histopathological changes and the high frequency of occurrence of severe changes in liver of Hypostomus cf. unae indicate that individuals are exposed to a stressor in this environment. Braunbeck et al. (1990) and Gonzalez et al. (1993) stated that as the liver is the largest metabolic organ, it comes into direct contact with pollutants absorbed from the water and Gernhöfer et al. (2001) and Van Dyk et al. (2007) argued that injuries in this organ are often associated with polluted aquatic environment. Peebua et al. (2008) have reported that injuries are majorly associated with the presence of pesticides. Heath (1995) reported that liver of the fish is sensitive to environmental agents because many contaminants tend to accumulate in the liver at much higher levels than in the other organs.

The high frequency of vacuolization of the hepatocytes has suggested that the samples were probably suffering the action of some 
stressor released into the environment (Abdel-Moneim and Abdel-Mohsen, 2010). According to Cheville (1994), a significant increase in the number of lipid vesicles on the cytoplasm reflects the decreased synthesis of proteins that follows injuries of the hepatocytes and blocks the use of lipidprotein conjugation. Van Dyk et al. (2007) examined the liver of Oreochromis mossambicus experimentally exposed to cadmium and zinc and observed that the inhibition of protein synthesis and the accumulation of lipids are associated with the response of hepatocytes to toxic agents. Fanta et al. (2003) have pointed out that the process of vacuolation can either denote the normal functioning of the liver or indicate a state of stress due to high energy demand.

In examining the liver of Astyanax jacuhiensis collected from stabilization ponds at Complexo do Pólo Petroquímico do Sul (Petrochemical Complex) Flores-Lopes and Malabarba (2007) have also observed a vacuolization of hepatocytes and thus associated the occurrence of such alterations to the presence of pollutants. Vinidhini and Narayanan (2008) have observed similar results after examining the effect of heavy metals on the livers of Cyprinus carpio.

Histological analyses have revealed that such changes usually occur along with other modifications, such as rectilineation of sinusoidal vessels, cells with cytoplasmic degeneration, constant presence of lymphocytes and macrophages, and congestion of sinusoidal vessels.

Among the moderate alterations observed at point 1 and 2, the rectilineation of the liver parenchyma can be a good indicator of the quality of the environment, since this type of alteration occurs after a long period of exposure. Therefore, it has been shown that the body is constantly subjected to the action of a stressor, as confirmed by Flores-Lopes and Malabarba (2007) and Paulo et al. (2012), who demonstrated that this type of alterations results from the continuous action of stressors on the body over a long period of time. The occurrence of this type of alteration demonstrates that the water quality of the environments are undergoing important changes in its constitution, being much influenced by the presence of several types of polluting substances, that will cause several types of alterations in the diverse species types. Factors such as this demonstrate that environments are undergoing various types of modifications and changing their environmental quality. Schwaiger et al. (1997), Peebua et al. (2006, 2008), Flores-Lopes and Malabarba (2007) and Paulo et al. (2012) have reported that the high frequency of these cell types may indicate that these organs are subject to stress in the aquatic environment.

The results obtained by semi-quantitative analysis and analysis of HAI have revealed that the quality of water of Limoeiro stream is reasonable, since data regarding specimens from point 1 only indicated light changes in the organ, whereas those relative to point 2 exhibited a low frequency of moderate changes, reflecting the environmental conditions wherein the animals lived and these results indicated that if the river conditions improve, the organs can recover.

The results are in line with those described by Poleksic and Tutundzic-Mitrovic (1994), Schwaiger et al. (1997), Van Dyk et al. (2007), Flores-Lopes and Thomaz (2011) and Paulo et al. (2012), who have reported that the 
occurrence of pathological changes on a small scale is associated with the environmental quality of the site and the high frequency of pathological changes is associated with degraded areas. In the opinion of these authors, tests aimed at examining the morphological changes of organs are some of the possible methods to evaluate the effects of pollutants on freshwater fishes. Flores-Lopes and Malabarba (2007), van Dyk et al. (2007), Flores-Lopes e Thomaz (2011) and Paulo et al. (2012) have also associated such high frequencies of moderate alterations to degraded environments.

Despite the results from Mann-Whitney test and ANOVA were not considered statistically significant, the observed data reveal that point 2 suffered higher degradation than point 1 due to the fact that in point 2 , we have observed a higher frequency of severe and moderate changes than at point 1.

The occurrence of high frequency of severe changes in samples collected from Limoeiro stream was probably due to the fact that the sampling points were environmentally compromised due to not having riparian vegetation, suffer with the dumping of sewage and the presence of waste from human activities (Trindade et al., 2010). This result is reinforced by fact that these places are influenced by stressors originated from urban areas, which compromise the water quality of these ecosystems. In these points, human influence may be encountered, with the discharge of domestic and pastoral activities from the urban perimeter. According to Klump et al. (2002), the major impact on this type of environment is the deterioration of water quality by organic matter and nutrients (phosphorus and nitrogen), biochemical oxygen demand (BOD), and the presence of solids and fecal coliforms released into the water through untreated sewage, giving rise to several negative effects on the receptor bodies. These types of stressors are insufficient to cause severe pathologies in individuals.

Paulo et al. (2012) have noted that the Cachoeira river, which receives the waters from Limoeiro stream after these cross the Colônia river, had elevated histopathological changes at the three studied points, revealing a high degree of deterioration. The authors have also found that the HAI means were associated with the contamination of the river waters.

The results of this study have revealed that the Limoeiro stream had a reasonable environmental quality, probably because the studied sites were located near the river source and by the fact that there were only a few small sources of pollution in the surrounding areas. The occurrence of histopathological changes in the liver of Hypostomus cf. unae serves as a warning for a potential increase in environmental degradation. More detailed studies based on the use of different methods are needed so as to achieve a more accurate diagnosis of the environmental quality, especially when it comes to the action of chemicals.

\section{References}

Abdel-Moneim AM and Abdel-Mohsen HA. (2010) Ultrastructure changes in hepatocytes of catfish Clarias gariepinus from Lake Mariut, Egypt. J. Environmental Biol. 31: 715 - 720.

Abdel-Warith AA, Younis EM, Al-Asgah NA and Wahbi 0 M. (2011) Effect of zinc toxicity on liver histology of Nile tilapia, Oreochromis niloticus. Scientific Research Essays 6: 3760 - 3769. 
Adams SM. (1990) Status and use of biological indicators for evaluating the effects of stress on fish. American Fish Society Symposium 8: 1-8.

$\mathrm{Au}$ DWT. (2004) The application of histocytopathological biomarkers in marine pollution monitoring: a review. Marine Pollution Bulletin 48: 817- 834.

Bernet D, Schmidt $H$ and Meier W. (1999) Histopathology in fish: proposal for a protocol to assess aquatic pollution. J. Fish Diseases 22: 25-34.

Bengtsson BE, Carlin CH, Larsson A and Svanberg 0. (1975) Vertebral damage in minnows, Phoxinus phoxinus L., exposed to cadmium. Ambio. 4: 166168.

Britski HA, Silimon KA S and Lopes BS. (1999) Peixes do Pantanal. Manual de Identificação. Brasilia: Embrapa - SPI; Corumbá: Embrapa - CPAP, 184 p.

Braunbeck JB, Storch V and Bresch H. (1990) Speciesspecific reaction of liver ultraastructure in zebrafish (Brachydanio rerio) and trout (Salmo gairdneri) after prolonged exposure to 4-chloroamine. Archives Environmental Contamination Toxicology 19: 405- 418.

Bruslé J and Anadon, G G. (1996) The structure and function of Fish liver. p.77 - 78. In: Ibid. (Eds): Fish Morphology: Horizon of new research. A. A. Balkema Publishers, Brook_ield, USA, 549 p.

Cheville NF. (1994) Ultrastructural Pathology. Ames. Iowa State University Press, 586 p.

Fanta E, Rios FS, Viana M and Freiber GR. (2003) Histopatology of the fish Corydoras paleatus contaminated with sublethal levels of organophosphorus in water and food. Ecotoxicology Environmental Safety 54: 119-130.

Flores-Lopes F and Malabarba LR. (2007) Alterações histopatológicas observadas no fígado do lambarí Astyanax jacuhiensis (Cope, 1894) (Teleostei, Characidae) sob influência de efluentes petroquímicos. Biociências 15: 166- 172.

Flores-Lopes F and Thomaz AT. (2011) Histopathologic alterations observed in fish gills as a tool in environmental monitoring. Brazilian J. Biology 71: 179- 188.

Gernhöfer M, Pawert M, Schramm M, Müller E and Triebskorn R. (2001) Ultrastructural biomarkers as tools to characterize the health status of fish in contaminated stream. J. Aquatic Ecosystem Stress Recovery 8: 241- 260.

Gonzalez G, Crespo S and Bruske J. (1993) Histocytological study of the liver of the cabrilla sea bass, Serranus cabrilla (Teleostei, Serranidae), an available model for marine fish experimental studies. J. Fish Biology 43: 363- 373.

Heath AG. (1995) Water pollution and fish physiology. CRC Press, Boca Raton, Florida, 369 p.

Hose JE, McGurk MD, Marty GD, Hinton DE, Brown ED and Baker TT. (1996) Sublethal effects of the Exxon Valdez oil spill on herring embryos and larvae: morphological, cytogenetic, and histopathological assessments, 1989 - 1991. Canadian J.l Fish Aquatic Sci. 53: 2355- 2365.

Jenkins JA. (2004) Fish bioindicators of ecosystem condition at the Calcasieu Estuary, Louisiana. USGS Open-File Report, 47 p.

Karr JR. (1981) Assessment of biotic integrity using fish communities. Fisheries 6: 21- 27.

Klumpp A, Bauer K, Franz-Gerstein C and Menezes M. (2002) Variation of nutrient and metal concentrations in aquatic macrophytes along the rio Cachoeira in Bahia (Brazil). Environmental International 28: 165-171.

Lucio MZTPQL, Santos SS and Silva DM L. (2012) Hydrochemistry of Cachoeira River (Bahia State, Brazil). Acta Limnologica Brasiliensia, 24: 181- 192.

Mangabeira P AO, Labejof L, Lamperti A, De Almeida A A, Oliveira FA H, Escaig F, Severo MI G, Silva D Da C, Salões M, Mielke MS, Lucena ER, Martins MC, Santana KB, Gavrilov KL, Galle P and Levi-Setti R. (2004) Accumulation of chromium in root tissues of Eichhornia crassipes (Mart.) Solms. in Cachoeira river - Brazil. Applied Surface Science 231-232: 497-501.

Mazzoni R, Fenerich-Verani $\mathrm{N}$ and Caramaschi EP. (2000) Electrofishing as a sampling technique for coastal stream fish populations and communities in the southeast of Brazil. Revista Brasileira de Biologia 60: 205- 216.

Mazzoni R, Rezende CF and Manna LR. (2010) Feeding ecology of Hypostomus punctatus Valenciennes, 1840 (Osteichthyes, Loricariidae) in a costal stream from Southeast Brazil. Brazilian J. Biology 70: 569574.

Michalany J. (1980) Técnica histológica em Anatomia Patológica, com instruções para o cirurgião, enfermeira e citotécnico. São Paulo, EPU, p. 277

Miranda JC and Mazzoni R. (2003) Composição da ictiofauna de três riachos do alto rio Tocantins, GO. Biota Neotrop. 3: 1-11.

Nacif PGS. (2000) Ambientes naturais da bacia hidrográfica do rio Cachoeira, com ênfase nos domínios pedagógicos. Viçosa: Universidade Federal de Viçosa. p.147. 
Navas-Pereira D and Henrique R (1996) Aplicação de índices biológicos numéricos na avaliação da qualidade ambiental. Revista Brasileira de Biologia 56: 441- 50.

Paulo DV, Fontes FM and Flores-Lopes F. (2012) Histopathological alterations observed in the liver of Poecilia vivipara (Cyprinodontiformes: Poeciliidae) as a tool for the environmental quality assessment of the Cachoeira river, BA. Brazilian J. Biol. 72: 131140.

Peebua P, Kruatrachue M, Pokethityook P and Kosiyachinda P. (2006) Histological effects of contaminated sediments in Mae Klong river tributaries, Tailand, on Nile tilapia, Oreochromis niloticus. Science Asia 32: 143 -150.

Peebua P, Kruatrachue M, Pokethitiyook $\mathrm{P}$ and Singhakaew S. (2008) Histopathological alterations of Nile tilapia, Oreochromis niloticus in acute and subchronic alachlor exposure. J. Environ. Biol. 29: $325-331$.

Petcoff G M, Díaz AO, Escalante AH and Goldemberg AL. (2006) Histology of the liver of Oligosarcus jenynsii (Ostariophysi, Characidae) from Los Padres Lake, Argentina. Iheringia 96: 205- 208.

Poleksic V and Mitrovic-Tutundzic V. (1994) Fish gills as a monitor of sublethal and chronic effects of pollution. p. 339 - 352. In: Müller, R. and Lloyd, R. (Eds.). Sublethal and Chronic effects of Pollutants on Freshwater Fish. Cambridge, Cambridge Univ. Press, UK. p. 487.

Rubert M, Zawadzki CH and Giuliano-Caetano L. (2008) Cytogenetic characterization of Hypostomus nigromaculatus (Siluriformes, Loricariidae) . Neotropical Ichthyology 6: 93-100.

Schwaiger J, Wanke R, Adam S, Pawert M, Honnen W and Triebskorn R. (1997) The use of histopathological indicators to evaluate contaminant-related stress in fish. J. Aquatic Ecosystem Stress Recovery 6: 75- 86.
Schwaiger J, Ferling $\mathrm{H}$, Mallow U, Wintermayr $\mathrm{H}$ and Negele RD. (2004) Toxic effects of the non-steroidal anti-inflammatory drug diclofenae. Part I: histopathological alterations and bioaccumulation in rainbow trout. Aquatic Toxicology 68: 141-150.

Stegemen JJ and Lech JJ. (1991) Cytochrome P-450 monooxygenase systems in aquatic species: carcinogen metabolism and biomarkers for carcinogen and pollutant exposure. Environ. Hlth. Perspect 90:101-109.

Souza V L, Silva D C, Santana K B, Mielke M S, Almeida A. AF, Mangabeira PAO and Rocha EA. (2009) Efeitos do cádmio na anatomia e na fotossíntese de duas macrófitas aquáticas. Effects of cadmium on the anatomy and photosynthesis in two aquatic macrophyte. Acta Botanica Brasilica, 23: 343- 354.

Suzuki HI, Pavanelli C S, Fugi R, Bini LM and Agostinho AA. (1997) Ictiofauna de quatro tributários do reservatório de Segredo. p.259 - 273. In: Agostinho AA and Gomes LC. (Ed). Reservatório de Segredo bases ecológicas para o manejo. Maringá - EDUEM, p. 253.

Trindade MEJ, Cetra M and Jucá-Chagas R. (2010) Ictiofauna do Ribeirão Limoeiro, Bacia do rio Cachoeira, BA. Biota Neotropica 10: 111-117.

Van Dyk JC, Pieterse GM and van Vuren JHJ. (2007) Histological changes in the liver of Oreochromis mossambicus (Cichlidae) after exposure to cadmium and zinc. Ecotoxicology Environmental Safety 66: 432-440.

Vinodhini R and Narayanan M. (2008) Bioaccumulation of heavy metals in organs of fresh water fish Cyprinus carpio (Common carp). Instrumental J. Environmental Science Technology 5: 179-182.

Zar JH. (1999) Biosestatistical Analysis. 4a Ed., Prentice-Hall Editora, New Jersey. p. 663. 